Norris, L. C. (1955). Proc. roth Distillers Feed Research Conference, Cincinnati, p. 39.

Novak, A. F. \& Hauge, S. M. (1948). F. biol. Chem. 174, 647.

O'Dell, B. L. \& Savage, J. E. (1957). Poult. Sci. 36, 459.

Rasmussen, R. A., Luthy, P. W., Van Lanen, J. M. \& Boruff, C. S. (1957). Poult. Sci. 36, 46.

Scott, M. L. (1957). Proc. 12th Distillers Feed Research Conference, Cincinnati, p. 61.

Synold, R. E., Carrick, C. W., Roberts, R. E. \& Hauge, S. M. (1943a). Poult. Sci. 22, 323.

Synold, R. E., Carrick, C. W., Roberts, R. E. \& Hauge, S. M. (1943b). Poult. Sci. 22, 336.

Yates, F. (1933). F. agric. Sci. 23, 108.

\title{
The influence of the route of administration on the effect of hexoestrol on fattening wether lambs
}

\author{
By T. R. PRESTON AND ISOLINE GEE* \\ Rowett Research Institute, Bucksburn, Aberdeenshire \\ (Received 22 fuly 1957-Revised I 3 fanuary 1958)
}

The administration of hexoestrol to livestock has been found by many workers to increase the rate of live-weight gain. It has been shown that hexoestrol treatment of lambs alters their metabolism in such a way that absorbed nutrients are diverted, in part, from fat anabolism to bone and muscle anabolism (Gee \& Preston, 1957). Since fat has a much higher calorific value per unit weight than either bone or muscle, and is generally stored with relatively little water, it follows that a given intake of food will produce a greater live-weight gain in a lamb treated with hexoestrol than in a lamb that has not been treated.

An increase in efficiency of conversion of food to live weight as a result of hexoestrol treatment has been reported by many investigators. More detailed carcass studies (Gee \& Preston, 1957) showed that treated lambs were 33\% more efficient in converting food protein to muscle protein but that efficiency of energy conversion was not affected by treatment. If these changes are desirable the findings would appear to justify the use of hexoestrol treatment in commercial lamb and mutton production (Preston \& Gee, 1957).

In our previous experiments treatment of lambs was mainly by subcutaneous implantation in the left ear of a single $15 \mathrm{mg}$ pellet of hexoestrol. In poultry one of the factors governing the rate of absorption of the hormone is the surface area of the pellet (Lorenz, 1954). Division of the standard $15 \mathrm{mg}$ pellet into three $5 \mathrm{mg}$ portions would be a possible way of increasing absorption without increasing the total dose.

Synthetic oestrogen may also be given by mouth in the food. Burroughs, Culbertson, Cheng, Hale \& Homeyer (1955) believe that objectionable side-effects, mainly slackening of the pelvic ligaments and mammary development, are less when cattle are fed stilboestrol than when the hormone is implanted subcutaneously.

\footnotetext{
* In receipt of a scholarship from the Ministry of Agriculture, Fisheries and Food.
} 
A comparison was therefore made of the relative effects of four methods of administering hexoestrol on the growth and certain carcass characteristics of wether lambs.

\section{EXPERIMENTAL}

Treatment of lambs. Fifty Suffolk $\times$ Greyface 5-month-old wether lambs were allocated to five groups. Group A were controls. Group B had implanted subcutaneously in the left ear a $15 \mathrm{mg}$ pellet of hexoestrol. Group C received two $5 \mathrm{mg}$ pellets of hexoestrol in the left ear and a third $5 \mathrm{mg}$ pellet in the right ear. Lambs in group D were given in the ration $2 \mathrm{mg}$ hexoestrol per head daily, the total dose in the trial period being $0.186 \mathrm{~g}$. Lambs in group $\mathrm{E}$ received $4 \mathrm{mg}$ per head daily, the total dose being $0.388 \mathrm{~g}$.

Lambs were given daily $50 \mathrm{~g}$ hay, and concentrates to appetite. The concentrate mixture was: maize meal 30 , flaked maize 20 , bran 10 , molassine meal* 10 , barley meal 10 and decorticated groundnut meal $20 \%$. The hexoestrol for groups D and E was incorporated in the diet at the rate of $\mathrm{Ig}$ to $50 \mathrm{~kg}$ of concentrates, and $\mathrm{I} 00$ and $200 \mathrm{~g}$ of this mixture were fed to each lamb of groups $\mathrm{D}$ and $\mathrm{E}$ respectively. The remainder of the concentrate ration consisted of the unsupplemented mixture.

The lambs were housed individually indoors for about 90 days and were slaughtered when they reached a live weight of $50 \mathrm{~kg}$.

Slaughter technique. Immediately after slaughter the warm carcass was weighed. The teats were cut off close to the udder, measured and weighed. The thyroid glands and pituitary body were dissected out and weighed. The carcasses were left to cool for $24 \mathrm{~h}$, reweighed and measurements taken of the length of leg $(F)$ and width of hindquarters $(G)$ (Pálsson, I939). The left leg was separated from the carcass by a transverse cut through the lateral muscles at the level of the articulation of the femur with the acetabulum of the pelvis. The leg was then disarticulated and cut along the ischial arch as close to the bone as possible. The joint was weighed and dissected into edible meat and bone. These tissues were weighed and the edible meat was minced to obtain a representative sample which was stored at $-20^{\circ}$. Each sample was freezedried, minced again and analysed for fat (Callow, 1944), residual moisture and ash. Protein was calculated as $90 \%$ of the dry fat-free residue (Callow, 1944).

The ears from the implanted animals were kept after slaughter and the remaining pieces of pellets were dissected out, dried and weighed.

\section{RESULTS}

Most of the lambs lost weight during the first 2 weeks of the experiment. This setback was probably due to a too rapid change-over from pasture to a high-concentrate diet.

Four lambs, one from each of the groups A, B, D and $\mathrm{E}$ had difficulty in urination and oedema of the anal area: they were slaughtered before the end of the experiment. In each lamb urinary calculi, mainly calcium phosphate, were present in the penile region of the urethra.

\footnotetext{
* Contains $75 \%$ molasses and $25 \%$ sphagnum moss (Molassine Co. Ltd, Greenwich, London, S.E. 10).
} 
Live-weight gains, food-conversion rates, carcass weights and measurements, and dressing out percentages (see Gee \& Preston, 1957) for the five groups of lambs are set out in Table I. Although overall differences in daily live-weight gain between treatments were not significant, the difference between the control and the other four treatments taken together was in itself significant at the $5 \%$ level and showed the rate of gain to be higher for the treated than for the untreated lambs. Treated lambs required less food per unit of live-weight increase than untreated lambs, which is in agreement with our earlier report (Gee \& Preston, 1957). There were no significant differences between treatments for dressing-out percentage or the ratio too $G: F$.

\section{Table I. Growth, food-conversion rate and carcass measurements of control and hexoestrol-treated lambs}

\begin{tabular}{|c|c|c|c|c|c|c|}
\hline & $\begin{array}{l}\text { Group A } \\
\text { (control) }\end{array}$ & $\begin{array}{l}\text { Group B } \\
\text { (I5 mg } \\
\text { subcu- } \\
\text { taneously) }\end{array}$ & $\begin{array}{c}\text { Group C } \\
(3 \times 5 \mathrm{mg} \\
\text { subcu- } \\
\text { taneously) }\end{array}$ & $\begin{array}{l}\text { Group D } \\
\text { ( } 2 \mathrm{mg} \text { daily } \\
\text { in ration) }\end{array}$ & $\begin{array}{l}\text { Group E } \\
\text { ( } 4 \mathrm{mg} \text { daily } \\
\text { in ration) }\end{array}$ & $\begin{array}{l}\text { Standard error } \\
\text { of difference } \\
\text { between any } \\
\text { two treatments }\end{array}$ \\
\hline No. of lambs & 10 & 9 & IO & IO & 10 & - \\
\hline Initial weight (kg) & $32 \cdot I$ & $32 \cdot 9$ & $3 I \cdot 6$ & $32 \cdot 2$ & $31 \cdot 4$ & $\ldots$ \\
\hline Final weight (kg) & $49^{\circ} 9$ & $5 I \cdot 0$ & $50 \cdot 8$ & $50 \cdot 2$ & 50.5 & - \\
\hline Daily gain $(\mathrm{kg})$ & $0.174^{*}$ & 0.195 & $0 \cdot 208$ & $0 \cdot 193$ & $0 \cdot 197$ & \pm 0.013 \\
\hline $\begin{array}{l}\text { Food-conversion rate } \\
\text { (kg gain/kg food) }\end{array}$ & 0.168 & $0 \cdot 195$ & 0.210 & 0.192 & 0.194 & \pm 0.014 \\
\hline Carcass weight $(\mathrm{kg})$ & $24 \cdot 4$ & $24 \cdot 4$ & $24 \cdot 2$ & $24 \cdot 5$ & $24 \cdot 3$ & - \\
\hline Dressing-out percentage & $48 \cdot 9$ & $47 \cdot 9$ & $47 \cdot 7$ & $48 \cdot 9$ & $48 \cdot 3$ & \pm 0.8 \\
\hline Ratio, roo $G: F$ & $99^{\circ} \mathrm{I}$ & $97 \% 9$ & $97 \cdot 8$ & $102 \cdot 0$ & IOI.I & $\pm 2 \cdot 7$ \\
\hline
\end{tabular}

* Control group gained significantly less $(P<0.05)$ than groups $\mathrm{B}-\mathrm{E}$ taken together.

There were significant differences between treatments in the weight and length of rudimentary teats and in the weights of the thyroid gland and pituitary body (Table 2). All the hexoestrol-treated lambs showed greater development of the teats than did the controls. Weights of the thyroid glands and pituitary bodies were also heavier in the treated animals, with the exception of the thyroid weight for group B. For each measurement the highest value was recorded for lambs in group $\mathrm{E}$, which were given by mouth $4 \mathrm{mg}$ hexoestrol daily.

The weights of the leg joints, expressed as percentages of carcass weights, and the chemical composition of the leg joints for the five groups of lambs are presented in Table 3.

The leg joints of all groups of treated lambs contained significantly less fat and more muscle than those from control lambs. The percentage of bone was also increased by hexoestrol treatment although the differences between groups were not significant.

Group C lambs, which were treated with three $5 \mathrm{mg}$ pellets, absorbed $87 \%$ of the original implants while group B lambs which received one $15 \mathrm{mg}$ pellet absorbed only $69 \%$. This difference was significant at the $\mathrm{I} \%$ level.

Histological examination of the ears of lambs implanted with hexoestrol showed a localized area of fibrosis with an accumulation of pigmented phagocytic cells at the site of the injection. 


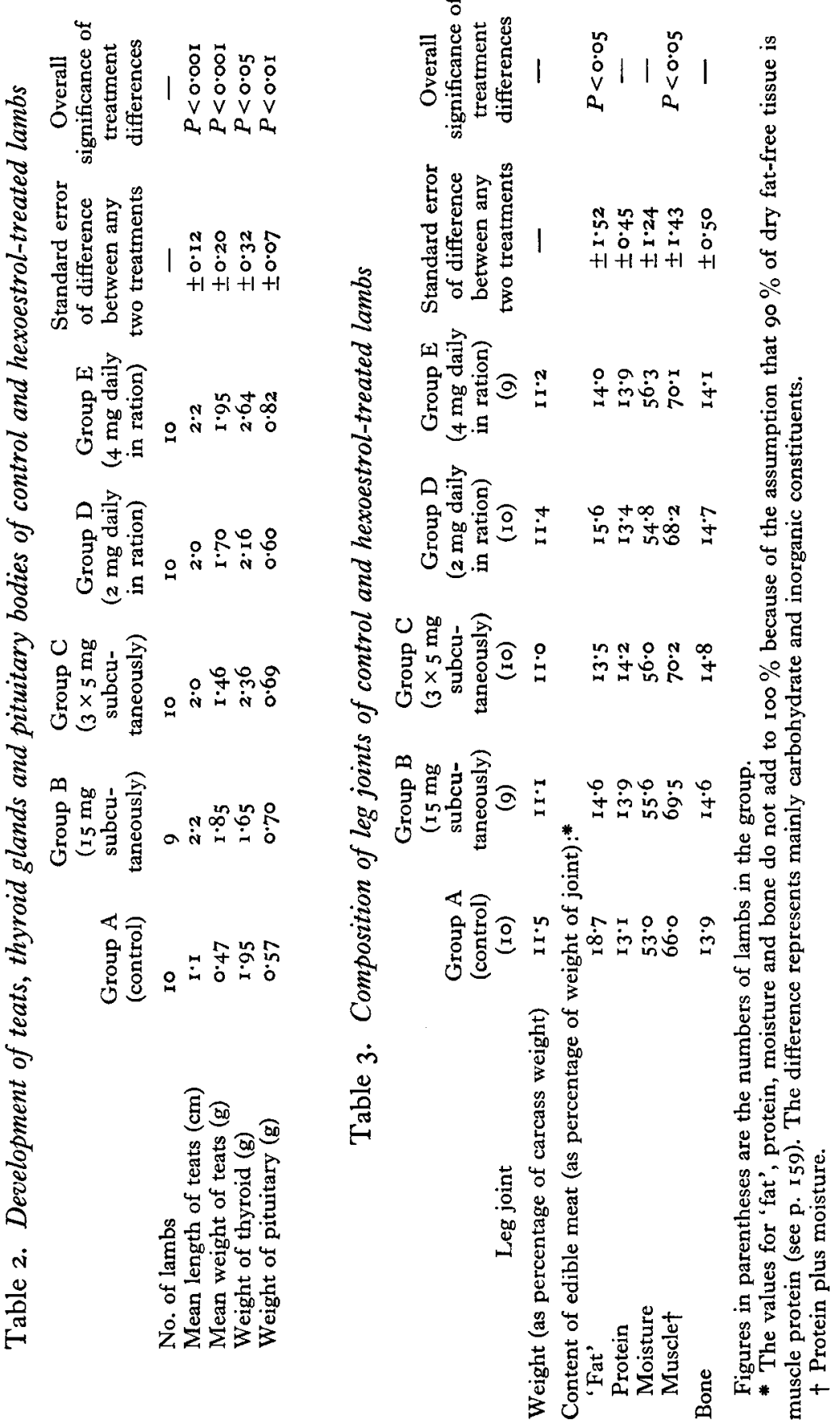




\section{DISCUSSION}

In several American experiments (Jordan, 1953; Bell, Smith \& Erhart, I954; Henneman, Rust \& Meites, 1957) there have been reports of urinary calculi in lambs treated with stilboestrol. In our experiment the presence of urinary calculi in a control lamb indicated that factors other than hexoestrol treatment were involved. The lambs were confined in small pens, and the lack of exercise combined with the high-concentrate diet may have been predisposing factors. In this connexion Elam, Schneider \& Ham (1956) reported a high incidence of calculi in wether lambs taken off a diet of lucerne hay and fed on rations containing over $50 \%$ of concentrates.

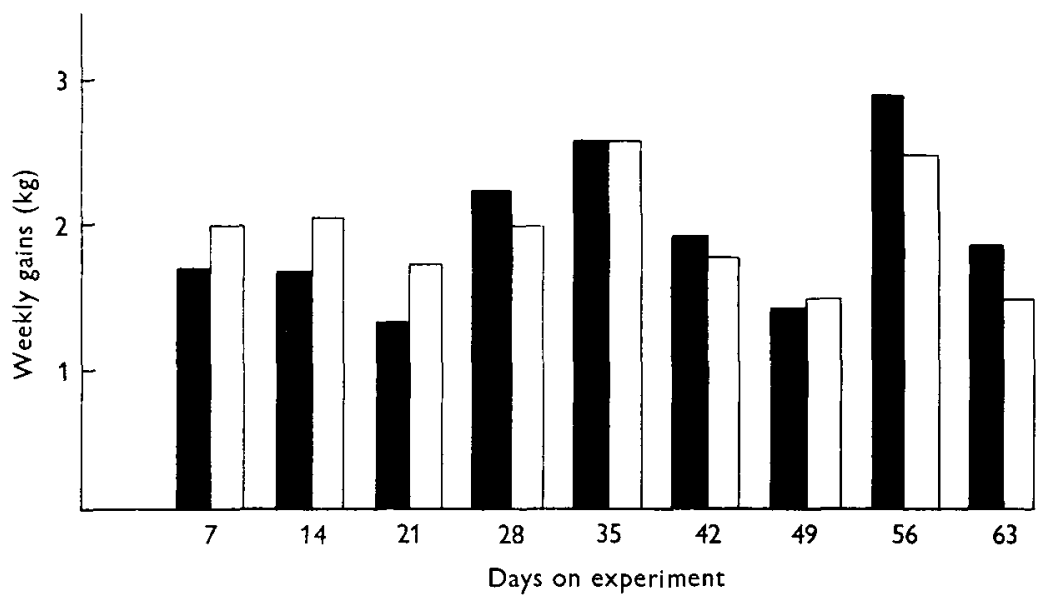

Fig. I. Mean weekly live-weight gains of lambs given hexoestrol in the ration (groups D and E, black columns) and lambs implanted with hexoestrol (groups $\mathrm{B}$ and $\mathrm{C}$, white columns).

The increase in daily live-weight gain with hexoestrol treatment is in agreement with the findings of most other workers. Expressed as a percentage of the daily weight gain made by control lambs, the weight gains made by groups $\mathrm{B}, \mathrm{C}, \mathrm{D}$ and $\mathrm{E}$ were I I 2, I I9, I I I and I I3 \% respectively. The significant increase in hexoestrol absorption and the slightly greater daily live-weight gain recorded for lambs implanted with three $5 \mathrm{mg}$ pellets compared with those that received a single $\mathrm{I} 5 \mathrm{mg}$ implant were probably due to the larger surface area of the smaller pellets, a suggestion that is in agreement with findings for poultry (Lorenz, I954). During the early stages of the experiment implanted lambs grew faster than those given hexoestrol in the diet (Fig. I). In the remaining weeks of the experiment the position was reversed and the greatest gains were made by lambs in groups $\mathrm{D}$ and $\mathrm{E}$, which would suggest that absorption from an implant is high in the first weeks after implantation but subsequently declines with diminishing surface area of the pellet and as fibrous tissue forms round the pellet. On the other hand, when hexoestrol is given in the ration one would expect the rate of absorption to be constant throughout the treatment period. If mammary development in wether lambs is an index of the amount of oestrogen being absorbed, then this 
hypothesis is supported since animals in group E showed greatest development of the rudimentary teats at the end of the experiment. Group E lambs also had the heaviest thyroid and pituitary glands which are other reported effects of oestrogen treatment.

The most marked effect of hexoestrol treatment was shown in the composition of the leg joints. The increase in bone and muscle and accompanying decrease in fat in all hexoestrol-treated lambs, compared with the controls, is in accordance with our earlier findings (Gee \& Preston, 1957). That fat content should be least and bone and muscle content greatest in the group gaining weight most rapidly and requiring least food per unit of live-weight increase supports the suggestion that hexoestrol stimulates bone and muscle anabolism at the expense of fat anabolism. This increase in the proportion of tissues of low calorific value, tissues, moreover, associated with more water than is fat, accounts for the greater increase in live weight of treated animals.

\section{SUMMARY}

I. Fifty 5-month-old wether lambs were allocated to five groups. Group A received no hexoestrol; lambs of group B were implanted with a $15 \mathrm{mg}$ pellet and those of group C with three $5 \mathrm{mg}$ pellets of hexoestrol. Group D were given $2 \mathrm{mg}$ hexoestrol per head daily in the ration and group $\mathrm{E} 4 \mathrm{mg}$.

2. Four lambs, one from each of groups $\mathrm{A}, \mathrm{B}, \mathrm{D}$ and $\mathrm{E}$, developed urinary calculi and were slaughtered before the end of the experiment.

3. Live-weight gains of groups B, C, D and E expressed as percentages of that of the untreated group A were II 2 , II 19 , II I and II $3 \%$ respectively. The differences between these figures were not statistically significant, but the mean gain for groups $\mathrm{B}$, $\mathrm{C}, \mathrm{D}$ and $\mathrm{E}$ considered together was greater than the mean gain in group $\mathrm{A}$.

4. Treated animals showed greater development of thyroid, pituitary and mammary glands.

5. The leg joints of treated lambs contained less fat and more muscle and bone than those of control lambs.

6. Lambs in group $\mathrm{C}$ absorbed significantly more of the implanted hexoestrol than those in group B.

We are indebted to $\mathrm{Mr} \mathrm{W}$. A. Boyne for carrying out the statistical analyses and to $\mathrm{Mr}$ B. F. Fell for histological examination of the ears from implanted lambs.

\section{REFERENCES}

Bell, T. D., Smith, W. H. \& Erhart, A. B. (1954). F. Anim. Sci. 13, 425. Burroughs, W., Culbertson, C. C., Cheng, E., Hale, W. H. \& Homeyer, P. (1955). F. Anim. Sci. 14, 1015.

Callow, E. H. (1944). F. agric. Sci. 34, 177.

Elam, C. J., Schneider, B. H. \& Ham, W. E. (1956). F. Anim. Sci. 15, 800.

Gee, I. \& Preston, T. R. (1957). Brit. F. Nutr. Ir, 329.

Henneman, H. A., Rust, R. E. \& Meites, J. (1957). F. Anim. Sci. 16, 283.

Jordan, R. M. (1953). F. Anim. Sci. 12, 680.

Lorenz, F. W. (1954). Vitam. \& Horm. 12, 235.

Pálsson, H. (1939). F. agric. Sci. 29, 544.

Preston, T. R. \& Gee, I. (1957). Proc. Brit. Soc. Anim. Prod. p. 4I. 